\title{
Profil Penyuluhan Yang Bersifat Edukatif Menyenangkan Dan Berwawasan Luas Dalam Upaya Meningkatkan Kesejahteraan Masyarakat
}

\author{
Nugraha Permana Putra' ${ }^{1}$, Robiatul Adawiyah ${ }^{2}$ \\ Universitas Muhammadiyah Cirebon \\ 1 e-mail: nugrahapermana1990@gmail.com \\ 2 e-mail: robiatul915@gmail.com
}

\begin{abstract}
ABSTRAK
Fenomena yang ada saat ini di lingkungan masyarakat adalah kurangnya wawasan yang mereka ketahui dan kurangnya edukasi yang mereka dapatkan, sehingga mereka cenderung monoton dan hanya melakukan hal-hal yang biasa mereka lakukan tanpa melakukan pembaharuan yang baru. Dalam hal mewujudkan kesejahteraan masyarakat perlu diadakan berbagai hal yang mampu menumbuhkan rasa keingintahuan yang besar. Sehingga masyarakat dapat ikut serta dalam penyuluhan atau memiliki rasa keingintahuan yang besar. Oleh karena hal itu dalam hal ini tujuan dari penyuluhan ini adalah mampu membuat masyarakat sadar akan pentingnya mereka memiliki edukasi tentang bagaimana cara agar dapat mencapai kesejahteraan. Ketika kita ingin melakukan sebuah edukasi kepada masyarakat maka ada beberapa hal yang harus kita perhatikan agar apa yang ingin kita edukasikan dapat diterima dan dipahami dengan baik sehingga mereka mampu melaksanakannya. Tahap yang harus di perhatikan terlebih dahulu adalah perencanaan, pelaksanaan, dan juga evaluasi. Apabila kegiatan ini berhasil maka harus terus dilkukan pembaharuan. Dan apabila kegiatan ini tidak berhasil maka harus melakukan perbaikan. Dengan adanya penyuluhan ini dapat membuat masyarakat menjadi lebih berwawasan luas sehingga mampu menciptakan hal-hal baru yang dapat bermanfaat untuk kesejahteraan masyarakat.
\end{abstract}

Kata Kunci: Penyuluhan, Edukatif, Kesejahteraan

\begin{abstract}
The current phenomenon in the community is the lack of knowledge they know and the lack of education they get, so they tend to be monotonous and only do things they usually do without doing new updates. In terms of realizing community welfare, various things need to be held that can foster a great sense of curiosity. So that people can participate in counseling or have a great sense of curiosity. Therefore, in this case, the aim of this counseling is to be able to make the community aware of the importance of having education on how to achieve prosperity. When we want to do learning to the community, there are some things that we must pay attention to so that what we want to educate can be accepted and understood well so that they are able to carry it out. The first step to consider in planning, implementing, and evaluating. If this activity is successful, renewal must continue. And if this activity is unsuccessful, the improvement must be made. This counseling can make the community more knowledgeable so that it can create new things that can benefit the welfare of the community.
\end{abstract}

Keywords: Counseling, Educational, Welfare 


\section{PENDAHULUAN}

Kurangnya kesejahteraan yang ada pada masyarakat sekarang cenderung disebabkan karena kurangnya mereka memahami tentang iptek maupun kurangnya wawasan yang mereka punya. Mereka hanya melaksanakan apa yang mereka tahu tanpa memikirkan apa sebenarnya yang harus mereka lakukan untuk menjadi lebih maju.

Hal lainnya juga bisa disebabkan karena terpencilnya desa yang mereka tinggali sehingga menjadi salah satu penyebab sukarnya informasi masuk ke desa tersebut. Ataupun kurangnya pemerintah dalam memperhatikan warganya. Hal ini tentu sangat berpengaruh sekali bagi masyarakat yang ada disana. Sehingga dalam penelitian kali ini kita akan memberikan penyuluhan yang bersifat edukatif dan berwawasan luas agar dapat menambah wawasan masyarakat tentang pentingnya memiliki kemampuan yang dapat membuatnya berkembang sehingga dapat menciptakan kesejahteraan dalam keluarnya maupun lingkungan sekitarnya.

\section{BAHAN DAN METODE}

Bahan ataupun metode dalam kegiatan ini sudah pasti harus ada. Bahan disini mencakup beberapa hal yang menjadi target penyuluhan pada kegiatan tersebut. Sedangkan metode itu sendiri merupakan sesuatu hal yang harus diperhatikan dan dilaksanakan agar tujuan yang kita inginkan dapat tercapai. Dalam penelitian ini peneliti menggunakan metode studi kasus. Dengan observasi dan survey adalah penelitian yang berusaha untuk mengungkapkan opini, pendapat atau pandangan masyarakat terhadap isu isu tertentu. Penelitian survey selalu melibatkan populasi subjek penelitian sebagai sumber data yang banyak bahkan kadang-kadang tak terhingga. Tujuan dari survey itu sendiri adalah untuk mengumpulkan data.

Data adalah bentuk jamak dari datum. Data merupakan keterangan-keterangan tentang suatu hal, dapat berupa sesuatu yang diketahui atau di anggap. Data merupakan kumpulan fakta atau angka atau segala sesuatu yang dapat dipercaya kebenarannya sehingga dapat di gunakan untuk menarik suatu kesimpulan. Adapun macam-macam data penelitian adalah: 


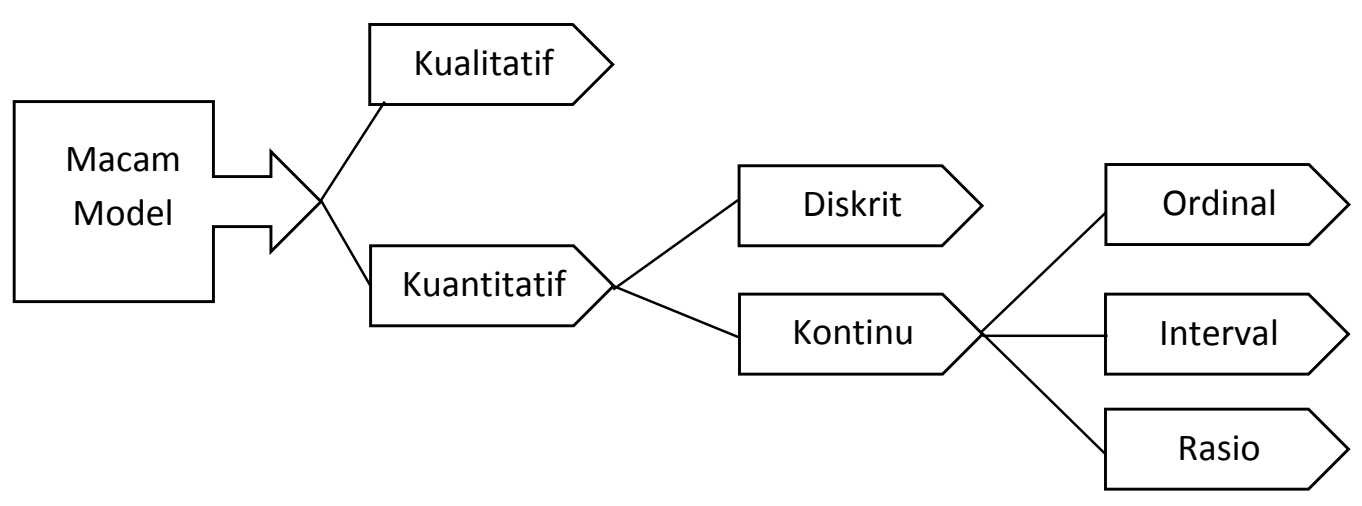

Gambar 1. Macam-macam Model Penelitian

Pengumpulan data statistik dapat dikumpulkan dengan menggunakan prosedur yang sistematis. Pengumpulan data dimaksudkan sebagai pencatatan peristiwa atau karakteristik dari sebagian atau selruh elemen Populasi. Data yang telah dikumpulkan (raw score) kemudian diolah. Pengolahan data di maksudkan sebagai proses untuk memperoleh data ringkasan dari data mentah dengan menggunakan cara atau rumus tertentu. Data ringkasan yang diperoleh dari pengolahan data itu dapat berupa jumlah (total), rata-rata, persentase, dan sebagainya. Data yang sudah diolah, agar mudah dibaca dan dimengerti oleh orang lain atau pengambilan keputusan, perlu disajikan dalam bentuk bentuk tertentu. Penyajian memiliki fungsi antara lain: (1) menunjukan perkembangan suatu keadaan, dan (2) mengadakan berbandingan pada suatu waktu. Selanjutnya penyajian data dapat dilakukan melalui tabel atau grafik.

Secara umum, variabel dibagi atas 2 (dua) jenis, yaitu variabel kontinu (continuous variabel) dan variabel deskrit (descrete variabel). Variabel dapat juga dibagi sebagai variabel dependen dan variabel bebas. Variabel biasanya di simbolkan dengan variabel $\mathrm{X}$ ataupun Variabel Y. Dalam penelitian kita harus menetapkan waktu maupun tempat penelitiannya. Untuk penelitian kali ini dilakukan di desa panongan Kecamatan Sedong mulai tanggal 10 Agustus 2019 sampai 10 September 2019.

\section{HASIL DAN PEMBAHASAN}

\section{Gambaran Umum Wilayah Desa Panongan}

Desa Panongan adalah salah desa yang berada di wilayah Kecamatan Sedong Kabupaten Cirebon dengan luas wilayah 265,5 Ha dengan jumlah penduduk sebanyak 4.821 jiwa yang terdiri dari 2.479 laki-laki dan 2.342 perempuan dengan jumlah kepala keluarga 1.481 kepala keluarga. Adapun batas-batas wilayah Desa Panongaan adalah sebagai berikut : 
Tabel 1. Perbatasan Desa Panongan

\begin{tabular}{ccc}
\hline Batas & Desa & Kecamatan \\
\hline Sebelah utara & Panongan Lor & Sedong \\
Sebelah Timur & Sedong Lor & Sedong \\
Sebelah Selatan & Windujaya & Sedong \\
Sebelah Barat & Putat & Sedong \\
\hline
\end{tabular}

Sumber: Data Primer, 2019

Dilihat dari topografi dan kontur tanah Desa Panongan Kecamatan Sedong secara umum berupa tanah seluas 265,5 Ha, tanah darat seluas 265,5 Ha , yang berada pada ketinggian laut antara $115 \mathrm{~m}$ s/d $120 \mathrm{~m}$ diatas permukaan laut dengan suhu berkisar antara 30 derajat celcius. Desa Panongan terdiri dari 3 Dusun/Blok, dengan 6 RW dan 20 RT.

Tabel 2. Orbitrasi Desa Panongan ke Pusat-pusat Pemerintahan

\begin{tabular}{lcl}
\multicolumn{1}{c}{ Orbitasi } & Volume & Satuan \\
\hline Jarak menuju ibukota Kecamatan & 0,25 & $\mathrm{Km}$ \\
Lama jarak tempuh dengan kendaraan bermotor & 3 & Menit \\
Jarak menuju ibukota Kabupaten & 35 & $\mathrm{Km}$ \\
Lama jarak tempuh dengan kendaraan bermotor & 1 & jam \\
Jarak menuju ibu kota provinsi & 143 & $\mathrm{Km}$ \\
Lama jarak tempuh dengan kendaraan bermotor & 4 & jam \\
\hline
\end{tabular}

Sumber: Data Primer, 2019

\section{Demografis Desa (Kependudukan)}

Demografi adalah studi ilmiah tentang penduduk, terutama tentang jumlah, sturuktur dan perkembangannya. Jumlah penduduk yang besar bisa menjadi modal dasar pembangunan sekaligus bisa menjadi beban pembangunan. Agar dapat menjadi dasar pembangunan maka jumlah penduduk yang besar harus disertai kualitas SDM yang tinggi. Penanganan kependudukan sangat penting sehingga potensi yang dimiliki mampu menjadi pendorong dalam pembangunan. Berkaitan dengan kependudukan, aspek yang penting antara lain perkembangan jumlah penduduk, kepadatan dan persebaran serta strukturnya. 
Tabel 3. Luas Wilayah Menurut Penggunaan

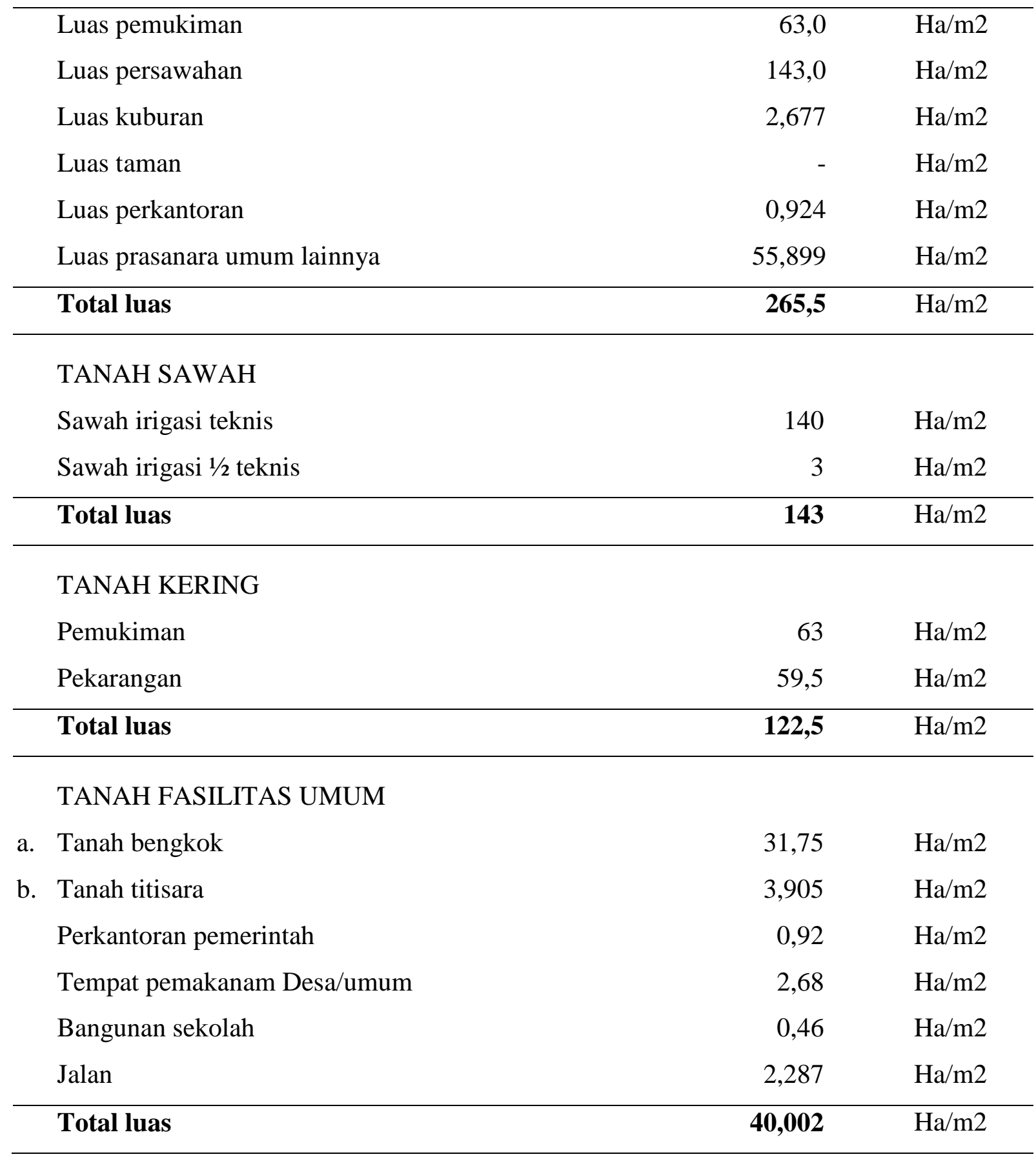

Sumber: Data Primer, 2019

Setelah kami melakukan survei lokasi dan melakukan wawancara dengan Pamong Desa beserta masyarakat desa Panongan kami mendapatkan beberapa permasalahan yang ada di desa tersebut. Selain permasalahan yang kami dapatkan, masyarakat pun mengharapkan perubahan didesanya demi kemajuan sumber daya alam dan sumber daya manusia yang ada. Informasi yang kami dapat ini adalah sebagai berikut: 


\section{Permasalahan di Desa Panongan yang Dilihat Berdasarkan Aspeknya}

\section{Ekonomi}

Ekonomi adalah aktivitas manusia yang berhubungan dengan produksi, distribusi, pertukaran, dan konsumsi barang dan jasa. Ekonomi secara umum atau secara khusus adalah aturan rumah tangga atau manajemen rumah tangga. Ekonomi juga dikatakan sebagai ilmu yang menerangkan cara-cara menghasilkan, mengedarkan, membagi serta memakai barang dan jasa dalam masyarakat sehingga kebutuhan materi masyarakat dapat terpenuhi sebaik-baiknya. Kegiatan ekonomi dalam masyarakat adalah mengatur urusan harta kekayaan baik yang menyangkut kepemilikkan, pengembangan maupun distribusian. Adapun prioritas masalah yang di dapat melalui survei dan wawancara terhadap aparatur pemerintah dan masyarakat adalah:

1. Kurangnya pemahaman dalam teknologi yang ada terhadap warga masyarakat dalam pola pikirnya (mindset).

2. Kurangnya pemahaman teknik dalam pemasaran terhadap suatu produk.

3. Kurangnya kreatifitas warga masyarakat dalam mengelola dan memasarkan produk yang sudah ada.

\section{Pendidikan}

Pengertian pendidikan secara sederhana dapat merujuk pada Kamus Besar Bahasa Indonesia (KBBI). Pendidikan merupakan proses perubahan sikap dan tatalaku seseorang atau kelompok orang yang dalam usaha mendewasakan manusia melalui upaya pengajaran dan pelatihan. Dari pengertian kamus terlihat bahwa melalui pendidikan satu orang mengalami perubahan sikap dan tata lku, dua orang berproses menjadi dewasa, menjadi matang dalam sikap dan tata laku, tiga berproses pendewasaan tersebut dilakukan melalui upaya pengajaran dan pelatihan.

Sementara itu, pendidikan menurut John Deway (Muslich, 2011: 167) adalah proses pembentukan kecakapan fundamental secara intelektual dan emosional kea rah alam dan sesame manusia. Tujuan pendidikan dalam hal ini agar generasi muda sebagai generasi penerus dapat menghayati, memahami, mengamalkan nilai-nilai atau norma-norma dengan cara mewariskan segala pengalaman, pengetahuan, kemampuan dan keterampilan yang melatar belakangi nilainilai dan norma-norma hidup dan kehidupan. Adapun perioritas masalah yang di dapat melalui survei dan wawancara terhadap aparatur pemerintah dan masyarakat adalah:

1. Kurangnya minat untuk melanjutkan pendidikan yang lebih tinggi, karna dipengaruhi oleh lingkungan.

2. Tidak adanya bimbingan belajar bagi siswa setelah sekolah. 
3. Kurangnya pembimbing ekstrakurlikuler di setiap Sekolah.

4. Kurangnya minat (motivasi) belajar peserta didik dalam mata pelajaran, yang meliputi Matematika, Bahasa Inggris dan Ilmu Pengetahuan Alam (IPA).

5. Kurangnya minat baca pada peserta didik

\section{Lingkungan dan Kesehatan}

Lingkungan adalah seluruh faktor luar yang memengaruhi suatu organisme; faktor-faktor ini dapat berupa organisme hidup (biotic factor) atau variabel-variabel yang tidak hidup (abiotic factor). Adapun perioritas masalah yang di dapat melalui survei dan wawancara terhadap aparatur pemerintah dan masyarakat adalah:

1. Tidak tersedianya Tempat Pembuangan Sementara sehingga warga membakar, mengubur atau membuang sampah secara liar di jalan.

2. Pengelolaan sampah belum optimal

3. Kurangnya kepedulian warga terhadap lingkungan

4. Perawatan sarana lingkungan yang kurang diperhatikan

5. Kurangnya optimalisasi lingkungan yang bisa dijadikan objek wisata

6. Kurangnya tenaga kesehatan

\section{Sosial, Budaya, Agama dan Olahraga}

Menurut Roucek dan Warren dalam Soekanto (2001:20) mengemukakan bahwa sosiologi adalah ilmu yang mempelajari hubungan antara manusia dalam kelompok-kelompok. Menurut Soemardjan dan Solaeman Soemardi dalam Soekanto (2001:21) menyatakan bahwa sosiologi atau ilmu masyarakat ialah ilmu yang mempelajari struktur sosial dan proses-proses sosial, termasuk perubahan-perubahan sosial. Menurut Koentjaraningrat (2000: 181) kebudayaan dengan kata dasar budaya berasal dari bahasa sansakerta "buddhayah", yaitu bentuk jamak dari buddhi yang berarti "budi" atau "akal”. Jadi Koentjaraningrat mendefinisikan budaya sebagai "daya budi" yang berupa cipta, karsa dan rasa, sedangkan kebudayaan adalah hasil dari cipta, karsa, dan rasa. Sementara menurut Elizabeth K. Nottingham dalam buku Jalaludin, agama adalah gejala yang begitu sering "terdapat di mana-mana", dan agama berkaitan dengan usahausaha manusia untuk mengukur dalamnya makna dari keberadaan diri sendiri dan keberadaan alam semesta.

Istilah olahraga terdapat dalam bahasa Jawa yaitu olahrogo. Olah artinya melatih diri menjadi seorang yang terampil sedangkan rogo artinya badan. jadi olahraga adalah suatu bentuk pendidikan individu dan masyarakat yang mengutamakan gerakan-gerakan jasmani yang dilakukan secara sadar dan sistematis menuju suatu kualitas yang lebih tinggi. Adapun perioritas 
masalah yang di dapat melalui survei dan wawancara terhadap aparatur pemerintah dan masyarakat adalah:

1. Kurangnya antusias warga untuk berpartisipasi dalam memajukan desa.

2. Paradigma masyarakat yang lebih memilih menjadi karyawan di luar desa ketimbang berwirausaha di desa sehingga dapat membuka lapangan pekerjaan

3. Kerjasama antar lembaga yang ada di desa belum maksimal.

4. Kurangnya antusias warga terhadap kegiatan kerja bakti.

5. Tidak adanya sarana untuk masyarakat khususnya anak-anak untuk mengenal permainan tradisional.

6. Kurangnya minat dan partipasi Masyarakat terhadap Program BUMDes yang di selenggarakan oleh pemerintahan

7. Pemahaman masyarakat dalam pengelolaan BUMDes yang kurang optimal

8. Kurangnya minat anak muda dalam mengembangkan potensi yang dimilikinya.

\section{Teknologi dan Informasi}

Teknologi informasi adalah berbagai aspek yang melibatkan teknologi, rekayasa, dan teknik pengelolaanyang digunakan dalam pengendalian dan pengelolaan informasi serta pennggunaannya. Adapun perioritas masalah yang di dapat melalui survei dan wawancara terhadap aparatur pemerintah dan masyarakat adalah:

1. Kurangnya pemanfaatan teknologi sebagai usaha

2. Belum terciptanya teknologi baru pada desa.

3. Masyarakat masih banyak yang belum mengenal IT/ilmu komunikasi

\section{Prioritas Permasalahan di Desa Panongan Berdasarkan Aspeknya}

\section{Pendidikan}

Kurangnya pemahaman siswa tentang cerita cerita rakyat yang ada di negeri kita sehingga anak-anak lebih kecanduan pada film-film kartun yang membuat fokus mereka terbagi. Dengan mnceritakan kembali cerita rakyat nusantara maka mampu menumbuhkan rasa cinta dan bangga mereka terhadap tanah air

\section{Sosial, Budaya, Agama dan Olahraga}

Kurangnya antusias remaja desa Panongan dalam Mengoptimalkan PHBI. Karena kurangnya antusiasme dari remaja dalam mengoptimalkan PHBI di desa Panongan, oleh karena itudiperlukan adanya peembinaan bagi para remaja untuk melakukan kegiatan kaegamaan. Tidak adanya petunjuk nama jalan maupun petunjuk rumah pejabat yang menyulitkan orang luar untuk 
mengetahui keadaaan didesa tersebut. Dengan membuat plangisasi maka akan memudahkan masyarakat dalam mengenali nama jalan maupun tempat-tempat pejabat daerah setempat.

Melaksanakan peringatan hari kemerdekaan 17 Agustus. Dengan melaksanakan peringatan hari kemerdekaan dapat menumbuhkan rasa nasionalisme dan rasa menghargi jasa para pahlawan. Hasil UMKM warga desa sedong yang masih dibilang pemasaran yang kurang dan harga yang di bawah standar. Karena dari produk tersebut tidak ada ciri khusus.

\section{Lingkungan dan Kesehatan}

Kegiatan warga yang hanya asyik dengan gadget nya dan malas untuk bergerak dapat menyebabkan beberapa macam penyakit. Kegiatan warga yang hanya asyik dengan gadgetnya menyebabkan warga kurang gerak ini dapat menyebabkan beberapa penyakit, oleh harena itu warga di harapkan agar dapat menggerakan anggota tubuhnya agar badan terasa bugar dan sehat. Dengan penggunaan label pada produk UMKM dan pengemasan yang dibuat sedemikian rupa mampu meningkatkan hasil jual dari produk trsebut, hasil jual yang meningkat mampu menunjang pereonomian warga.

Berdasarkan data hasil survei tersebut maka akan dilaksanakan beberapa program yang mampu mengedukasi dan menambah wawasan masyarakat. Adapun rencana program yang akan dilaksanakan adalah:

\section{Rencana Program Edukasi Masyarakat}

Setelah melaksanakan program maka dibuatlah beberapa rencana program yang akan dilaksanakan diantaranya adalah:

\section{Pendidikan}

\section{Si Geulis (Edukasi dan Gerakan Literasi)}

Melakukan bimbingan dan tutor cerita kepada anak-anak dan remaja yang ada di desa Panongan. Tujuan dari kegiatan ini yaitu untuk meningkatkan minat belajar dan pengetahuan tentang sejarah dan cerita rakyat anak-anak dan remaja. Sasaran kegiatan ini adalah Anak-anak. Tahapan pelaksanaan programnya yaitu: Minggu-1 (Pengenalan dan sosialisasi) Minggu-2 (Pelaksaaan tahap pertama) Minggu-3 (Evaluasi kegiatan) Minggu-4(Puncak kegiatan) dengan estimasi biaya sebesar Rp. 200.000,00-,

\section{Agama}

1. Panbers (Panongan Bersholawat)

Karena kurangnya antusiasme dari remaja dalam mengoptimalkan PHBI di desa Panongan, oleh karena itu diperlukan adanya pembinaan bagi para remaja untuk melakukan kegiatan 
keagaaman seperti tahlilan, peringatan maulid nabi dan pengajian. Sasaran kegiatan ini adalah Remaja. Adapun rancangan tahap kegiatan ini adalah Minggu-3 (Pengenalan dan sosialisasi) Minggu-2(Pelaksaaan tahap pertama) Minggu-3 (Evaluasi kegiatan) Minggu4(Puncak kegiatan), dengan estimasi biaya Rp. 100.000,00-,

\section{Sosial}

1. Panongan Fest

Sebuah kegiatan peringatan hari besar nasional yang dilaksanakan rutin setiap tahun oleh masyarakat desa guna meningkatkan rasa nasionalisme dan patriotisme, kegiatannya berupa perlombaan dan upacara memperingati dirgahayu republic Indonesia. Sasaran kegiatan ini adalah Masyarakat. Adapun rancangan kegiatan ini adalah Minggu-1 (Pengenalan dan sosialisasi) Minggu-2 (Pelaksaaan tahap pertama) Minggu-3 (Evaluasi kegiatan) Minggu-4 (Puncak kegiatan). Dengan estimasi biaya Rp. 200.000,00-,

\section{Ekonomi}

1. Gebrak (Gerakan ekonomi berbasis kerakyatan)

Pada kegiatan ini kita membuat sebuah koperasi milik dengan bekerja sama melali bumdes yang ada di desa. Sasaran dari kegiatan ini adalah Masyarakat . adapun rencana pelaksanaan kegiatan ini adalah Minggu-1 (Pengenalan dan sosialisasi) Minggu-2 (Pelaksaaan tahap pertama) Minggu-3 (Evaluasi kegiatan) Minggu-4(Puncak kegiatan)

2. Pandan Aran (Pelabelan Produk Rumahan dan Pemasaran)

Lebeling dan pemasaran merupakan sebuah program yang bertujuan untuk memberikan identitas produk dan memasarkan produk baik secara offline ataupun online guna meningkatkan daya jual dan pendapatan UMKM masyarakat desa Panongan. Sasaran kegiatan ini adalah masyarakat. Adapun rancanagan kegiatan ini adalah Minggu-1 (Pengenalan dan sosialisasi) Minggu-2 (Pelaksaaan tahap pertama) Minggu-3 (Evaluasi kegiatan) Minggu-4 (Puncak kegiatan).

\section{Kesehatan}

Penerapan Pola Hidup Sehat Merupakan sebuah program yang bertujuan untuk membiasakan masyarakat agar memiliki gaya hidup sehat. Sasaran kegiatan ini adalah Masyarakat. Adapun rencana kegiatan ini adalah Minggu-1 (Pengenalan dan sosialisasi) Minggu-2 (Pelaksaaan tahap pertama) Minggu-3 (Evaluasi kegiatan) Minggu-4 (Puncak kegiatan) adapun estimasi biayanya adalah Rp. 200.000. 


\section{Analisis Pelaksanaan Program Kerja}

\section{Panfest (Panongan Festival)}

a. Kesesuaian Realisasi dengan Target Kegiatan

Program ini dilakukan pada hari jum'at-sabtu 16-17 Agustus 2019. Program ini dilakukan untuk memperingati hari kemerdekaan republic Indonesia yang ke 74. Dalam program kerja ini terdapat berbagai perlombaan ang di lombakan dan banyak juga hiburan-hiburan yang ada di dalam rangkaian acar tersebut. Program kerja ini merupakan program kerja kelompok yag pertama di realisasikan. Sasaran dari kegiatan ini adalah seluruh warga masyarakat desa panongan dari berbagai kalangan dan usia.

b. Faktor-faktor pendukung Kegiatan

Kegiatan ini didukung oleh pejabat desa panongan, karang taruna batu lintang desa panongan, dan seluruh lapisan masyarakat yang ada di desa panongan.

c. Faktor-faktor kendala/hambatan dalam berkegiatan

Kendala maupun hambatan dalam kegiatan ini tidak ada. Kegiatan ini terbilang lancer. Adapun kendala yang ada mungkin hanya keterlambatan waktu dalam acara tersebut.

d. Kesesuaian pembiayaan

Di dalam proposal kami menganggarkan estimasi biaya kegiatan ini adalah Rp. 200.000,00,-. Namun pada pelaksanaannya kami hanya mengeluarkan biaya sebesar Rp. 150.000,00,-, karena biaya yang lainnya sudah di tanggung oleh pihak desa.

e. Peran serta warga dalam berkegiatan

Peran warga sekitar sangat antusias dan berperan aktif dalam kegiatan panongan festival.

f. Solusi untuk kegiatan selanjutnya

Solusi untuk program selanjutnya, memperbanyak lagi cabang perlombaan yang ada. Dan cabang perlombaan yang dilaksanakan sebaiknya mampu menumbuhkan kreatifitas yang lebih luas lagi.

\section{Si Gelis (Gerakan Literasi dan Edukasi)}

a. Kesesuaian Realisasi dengan Target Kegiatan

Program ini dilakukan pada hari senin 19 Agustus 2019 - 07 September 2019. Kegiatan ini adalah kegiatan yang mengajak anak-anak untuk gemar membaca. Pada pelaksanaannya dilakukan secara door to door. Kami menggunakan kendaraan roda tiga yang difasilitasi oleh pihak desa melakukan kunjungan ke beberapa titik yang ada didesa panongan untuk mengajak anak-anak membaca dan melukis hingga bercerita. Sasaran kegiatan ini adalah anak-anak desa panongan. 
b. Faktor-faktor pendukung Kegiatan

Kegiatan ini didukung oleh pejabat desa panongan, warga desa panongan dan anak-anak yang berada dilingkungan desa panongan.

c. Faktor-faktor kendala/hambatan dalam berkegiatan

Kendala maupun hambatan dalam kegiatan ini adalah kurangnya minat baca anak-anak dan anak-anak cenderung malu dan sungkan untuk ikut berkumpul dengan anak-anak yang lainnya.

d. Kesesuaian pembiayaan

Di dalam proposal kami menganggarkan estimasi biaya kegiatan ini adalah Rp. 200.000,00,-, dan pada saat pelaksanaan kegiatan dana yang dihabiskan sesuai dengan yang tertera dalam proposal.

e. Peran serta warga dalam berkegiatan

Peran warga sekitar sangat antusias dan berperan aktif dalam kegiatan "si gelis" ini.

f. Solusi untuk kegiatan selanjutnya

Solusi untuk program selanjutnya, lebih menyediakan buku bacaan yang menarik dan lebih lagi membuat sebuah hal yang dapat menarik minat siswa dalam membaca dan ikut berbaur dalam kegiatan ini.

3. Panongan Bersehat (Panongan Bersih dan Sehat)

a. Kesesuaian Realisasi dengan Target Kegiatan

Program ini dilakukan pada 26 Agustus-07 September 2019. Program ini dilakukan dengan tujuan agar seluruh warga desa panongan dapat lebih sehat lagi. Beberapa kegiatan yang dilakukan dalam kegiatan ini yaitu senam bersama, pembuatan atau penanaman apotek hidup yang di simpan dirumah salah satu warga hingga kegiatan pengadaan donor darah dengan bekerja sama dengan PMII Kabupaten Cirebon. Kegiatan ini memiliki sasaran pada warga desa panongan dan dari segala usia.

b. Faktor-faktor pendukung Kegiatan

Kegiatan ini didukung oleh pejabat desa panongan, dan masyarakat desa panongan.

c. Faktor-faktor kendala/hambatan dalam berkegiatan

Kendala dalam kegiatan ini adalah sulitnya mengumpulkan warga dalam semua kegiatan panongan bersehat ini. Namun warga yang ikut berpartisipasi juga tidak sedikit.

d. Kesesuaian pembiayaan

Di dalam proposal kami menganggarkan estimasi biaya kegiatan ini adalah Rp. 200.000,00,-, namun pada pelaksanaannya kami mengeluarkan biaya yang lebih yaitu 
sebesar Rp. 350.000,00,-. Biaya ini di keluarkan untuk konsumsi maupun untuk membeli tanaman obat yang dibutuhkan untuk pembuatan apotek hidup.

e. Peran serta warga dalam berkegiatan

Peran warga sekitar sangat antusias dan berperan aktif dalam kegiatan Panongan Bersehat ini.

f. Solusi untuk kegiatan selanjutnya

Solusi untuk program selanjutnya, memperbanyak lagi sosialisasi kepada warga di setiap lingkunga yang ada didesa panongan. Penyisiran wilayah yang lebih mendalam lagi.

4. Gebrak (Gerakan Ekonomi Berbasis Kerakyatan)

a. Kesesuaian Realisasi dengan Target Kegiatan

Program ini dilakukan pada hari Kamis 05 September 2019 dengan diadakannya mini seminar dan Lounching E- BUMDes ciputri.dengan adanya E-BUMDes diharapkan usahausaha milik desa dapat terekspos ke masyarakat las sehingga dapat memajukan usaha yang ada didesa panongan.

b. Faktor-faktor pendukung Kegiatan

Kegiatan ini didukung oleh pejabat desa panongan, pengurus BUMDes Ciputri, Selurus warga yang memiliki badan usaha, dan seluruh lapisan masyarakat yang ada di desa panongan.

c. Faktor-faktor kendala/hambatan dalam berkegiatan

Kendala maupun hambatan dalam kegiatan ini terdapat pada warga yang masih belum memahami apa itu BUMDes.

d. Kesesuaian pembiayaan

Di dalam proposal kami menganggarkan estimasi biaya kegiatan ini adalah Rp. 600.000,00,-, namun pada pelaksanaannya kami hanya mengeluarkan biaya sebesar Rp. 350.000,00,-.

e. Peran serta warga dalam berkegiatan

Peran warga sekitar sangat antusias dan berperan aktif dalam kegiatan Gebrak ini.

f. Solusi untuk kegiatan selanjutnya

Solusi untuk program selanjutnya sebaiknya dibuat penyuluhan secara menyeluruh ke warga tentang apa itu BUMDes dan apa fungsi Bumdes itu sendiri.

5. PanBers (Panongan Bersholawat)

a. Kesesuaian Realisasi dengan Target Kegiatan

Program ini dilakukan pada hari Sabtu-Minggu 31 Agustus -1 September 2019. Program ini dilakukan untuk memperingati tahun baru Islam 1 Muharram 1441 Hijriah. Dalam 
acara ini dimulai dengan pembacaan doa istigosah, arak arakan, pengadaan lomba-lomba dan ceramah yang di sampaikan pada hari minggu malam yang dihadiri oleh pejabat desa, para sepuh desa, pemuka agama dan masyarakat desa panongan yang bertempat di masjid baitul muttaqin dsa panongan.

b. Faktor-faktor pendukung Kegiatan

Kegiatan ini didukung oleh pejabat desa panongan, DKM Masjid Baitul Muttaqin dan seluruh lapisan masyarakat yang ada di desa panongan.

c. Faktor-faktor kendala/hambatan dalam berkegiatan

Kendala maupun hambatan dalam kegiatan ini tidak ada. Kegiatan ini terbilang lancar. Adapun kendala yang ada mungkin hanya keterlambatan waktu dalam acara tersebut.

d. Kesesuaian pembiayaan

Di dalam proposal kami menganggarkan estimasi biaya kegiatan ini adalah Rp. 100.000,00,-. Namun pada pelaksanaannya kami tidak mengeluarkan uang, dikarenakan dana dari acara tersebut di dapat dari kas desa panongan.

e. Peran serta warga dalam berkegiatan

Peran warga sekitar sangat antusias dan berperan aktif dalam kegiatan panongan festival.

f. Solusi untuk kegiatan selanjutnya

Solusi untuk program selanjutnya yaitu lebih di perbanyak lagi acara yang dilaksanakan dan lebih dalam lagi untuk melakukan sosialisasi kepada warga akan pentingnya perayaan tahun baru islam ini.

\section{Pandan Aran (Pelabelan Produk Rumahan dan Pemasaran)}

a. Kesesuaian Realisasi dengan Target Kegiatan

Program ini dilakukan untuk membuat produk rumahan yang ada di desa panongan dapat lebih luas lagi pemasarannya. Sasaran dari program ini adalah industry kecil yang dimiliki oleh warga desa panongan. Dengan program ini kita mengemas kembali produk yang ada dengan kemasan yang lebih menarik lgi dan memantu memasarkannya kepada public.

b. Faktor-faktor pendukung Kegiatan

Kegiatan ini didukung oleh pejabat desa panongan, Pengurus Bumdes, para pengusaha kecil dan seluruh lapisan masyarakat yang ada di desa panongan.

c. Faktor-faktor kendala/hambatan dalam berkegiatan

Kendala maupun hambatan dalam kegiatan ini tidak ada. Kegiatan ini terbilang lancar. Adapun kendala yang ada mungkin hanya pemasaran produk yang harus lebih luas lagi. 
d. Kesesuaian pembiayaan

Di dalam proposal kami menganggarkan estimasi biaya kegiatan ini adalah Rp. 200.000,00,-. Namun pada pelaksanaannya kami mengeluarkan biaya sebesar Rp. 400.000,00,- dikarenakan biaya kemasan yang baru dan label di produksi oleh kami.

e. Peran serta warga dalam berkegiatan

Peran warga sekitar sangat antusias dan berperan aktif dalam kegiatan panongan festival.

f. Solusi untuk kegiatan selanjutnya

Solusi untuk program selanjutnya, memperbanyak lagi cabang pemasaran. Agar produk rumahan yang terdapat di desa panongan dapat dikenal oleh public.

\section{Pelaksanaan penyuluhan}

Dalam melaksanakan penyuluhan banyak faktor yang harus diperhatikan diantaranya yaitu di antaranya tempat penyuluhan, audiens penyuluhan, pemateri dan materi penyuluhan. Penyuluhan juga harus mempunyai tujuan. Adapun tujuan dari penyuluhan adalah untuk menambah wawasan. Dalam penyuluhan harus terdapat beberapa hal yang harus diperhatikan yaitu:

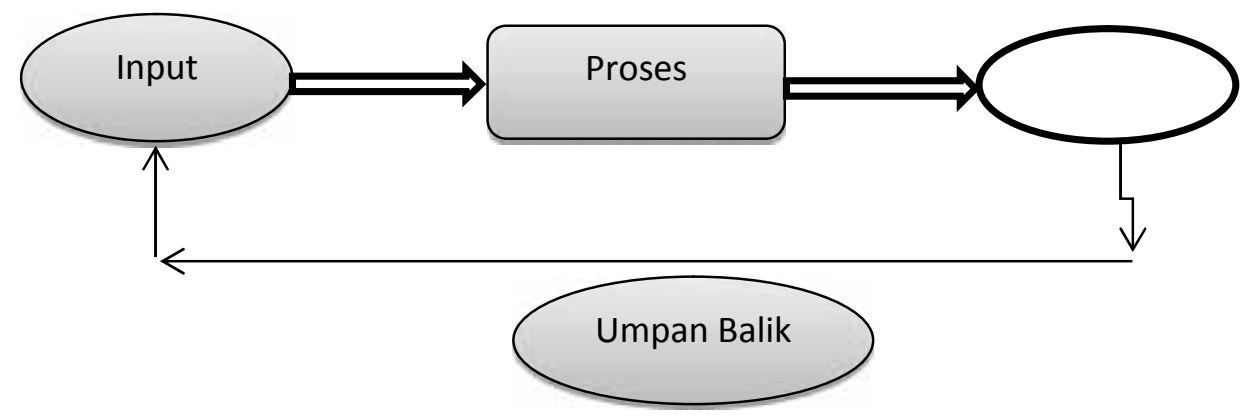

Gambar 2. Komponen-komponen Pelaksanaan Penyuluhan

\section{KESIMPULAN DAN SARAN}

Hasil dari kegiatan tersebut peneliti berhasil melaksanakan berbagai macam program kerja kelompok yang dilaksanakan dalam kurun waktu yang teah ditentukan oleh pihak universitas muhammadiyah Cirebon. Diantaranya adalah Panfest (Panongan Festival), Si Gelis (Gerakan Literasi dan Edukasi), Gebrak (Gerakan Ekonomi Berbasis Kemasyarakatan), Panongan Bersehat (Panongan Bersih dan Sehat), Pandan Aran (Pelabelan Produk Rumahan dan Pemasaran), dan PanBers (Panongan Bersholawat).

Semoga beberapa program kerja yang telah dipaparkan diatas dapat bermanfaat bagi masyarakat serta dapat ditindaklanjut dan menjadi masukan bagi kampus sebagai lembaga pendidikan yang 
turut serta menentukan perkembangan dan perubahan masyarakat. Saran yang membangun turut serta kami sampaikan untuk dijadikan bahan masukan sebagai evaluasi Kuliah Kerja Mahasiswa kedepan, yaitu lebih variatif lagi dlam pembuatan program kerja. Dalam memilih metode maupun penerapannya harus membuat beberapa perencanaan tambahan agar ketika satu perencanaan tidak terlaksana kita dapat menggunakan perencanaan yang selanjutnya.

\section{UCAPAN TERIMA KASIH}

Kegiatan pengabdian ini dapat terselenggara oleh adanya bantuan dan dukungan dari semua pihak terutama Perangkat Desa dan Masyarakat Desa Panongan Kecamatan Sedong Kabupaten Cirebon. Terima kasih.

\section{DAFTAR PUSTAKA}

Yulingga Nanda Hanif dan WasisHimawanto. 2007. Statistik Pendidikan. Yogyakarta: CV Budi Utama.

Prof. Dr. H.Wina Sanjaya. 2013. Penelitian Pendidikan: Jenis Metode dan Prosedur. Jakarta: Kencana.

Herni Sudarwati, dkk. 2019. Statistika dan Rancangan Percobaan (penerapan dalam bidang peternakan. Malang: UB Press.

Yusuf, Muri. 2017. Metode Penelitian: Kuantitatif, Kualitatif, dan Penelitian Gabungan. Jakarta: Kencana.

M. Sholahuddin. 2007. Asas-Asas Ekonomi Islam. Jakarta: PT. Raja Grafindo Persada.

Undang-Undang Kesehatan dan Rumah Sakit. 2010. Yogyakarta: Pustaka Yustisia.

Jalaludin. 2012. Psikologi Agama. Jakarta: PT. RajaGrafindo Persada.

Agoes Soegianto. 2010. Ilmu Lingkungan, Sarana Menuju Masyarakat Berkelanjutan. Surabaya: Airlangga University Press. 